Article

\title{
Efficiency Evaluation of Cultural Services in the Czech Republic via Multi-Criteria Decision Analysis
}

\author{
Roman Vavrek *(1) and Jiří Bečica \\ Department of Public Economics, Faculty of Economics, VŠB-Technical University of Ostrava, \\ Sokolská třída 33, 70200 Ostrava, Czech Republic; jiri.becica@vsb.cz \\ * Correspondence: vavrek.roman@gmail.com; Tel.: +420-597-322-334
}

Received: 12 March 2020; Accepted: 15 April 2020; Published: 22 April 2020

check for updates

\begin{abstract}
Culture is an irreplaceable means of transferring information between generations. The development of culture, the cultural environment, and the effect of culture exist over the long term. The results are not shown immediately, whereas the economics of subjects of this area (including theatres) are subject to public control. Public control forces these entities to use public finances efficiently, economically, and effectively. A sample of 11 indicators showing techniques and financial efficiency was chosen to conduct a complex evaluation of the economy of Czech theatres. The importance of the indicators was set by three objective methods used in combination by the Technique for Order of Preference by Similarity to Ideal Solution (TOPSIS) for the evaluation of management. We show significant differences among the results; in our opinion, it is not possible to exactly set the best method that could be applied in general. Every method can potentially serve as a tool for complex comparison among homogeneous groups of theatres of the Czech Republic, depending on the preferences of their founder, in the public sector such as a municipality, region, or state.
\end{abstract}

Keywords: culture; public good; MCDM; TOPSIS; coefficient of variance method; standard deviation method; mean weight method; indicator importance

\section{Introduction}

Culture is a significant factor in people's lives. It is part of the development of intellectual, emotional, and moral aspects of individuals in a given territory. Culture belongs to the sector of the national economy that supports public or mixed goods and services, except for the profit principle (e.g., media). Most of the subjects or activities in the area of dramatic art, which this paper focuses on, depend on contributions or subsidies by public budgets (financial or material), mainly because the market of these goods cannot ensure them in a range that is found suitable by political representation.

Within the Czech Republic, but in developed economies as well, only a very small number of cultural organizations can gain means for their activities only through their main activity, such as entrance fees or additional sales, purely based on the market. This leads founders and top representatives of states, regions, or municipalities to ensure certain kinds of cultural goods from public budgets. Based on the market, lower evaluated organizations would not be able to ensure mixed cultural goods without these public funds.

It was noted in [1] that assessing and comparing the socioeconomic benefits of different cultural sectors in cities is very important. It is stated in $[2,3]$ that assessing the cultural sector (with other industrial areas of the national economy) is a current trend in modern societies. It is further stated in $[4,5]$ that the economic importance of assessing cultural organizations can be evaluated in a variety of ways and approaches. According to [6], it is appropriate to use financial indicators that were originally 
designed for the private sector. It is noted in [7] that artistic or cultural value is usually converted into economic value. Culture professionals influence the population and change consumer behaviours and attitudes toward culture.

Evaluating these types of institutions from different points of view is also common abroad. The function of theatres in the US is reviewed in [8]. Similarly, theatres in Canada are evaluated in [9]. In European countries, the role of theatres is analysed in [10], evaluating their competitiveness in Romania. Theatres in the Czech Republic are evaluated in [11] in terms of providing a public good for the population; their profitability and financial self-sufficiency are evaluated in [12]. Comparisons in selected European cities were performed in $[1,13]$. This research shows an interesting finding, that all cultural institutions (including theatres) can become unique cultural centres that positively contribute to the strategic development of the served area (city, wider agglomeration, or region). These services cannot provide according to the profit principle in the market, which is the reason for evaluating economic-technical indicators of theatres in the Czech Republic. It is also confirmed abroad by [14]. In this context, Ruston, Peacock or Throsby [15-18] focus more on the importance of public funding; Frey and Volz $[19,20]$ add that economic and cultural approaches to management are also important.

The aim of the present research is to evaluate the management of theatres in the Czech Republic with respect to the efficiency of management using a multi-criteria evaluation showing the complex real state of the evaluated subjects. In order to achieve this aim, the problems of culture are discussed and public goods in culture are evaluated with a focus on theatrical creations in the Czech Republic in the first part of the paper. Two research questions and three hypotheses are defined for subsequent verification with the methodology in Section 4, where the research file, the structure of the observed indicators, and the methods used are characterized. The research part first focuses on the identification and importance of indicators based on three objective methods and subsequent descriptions and comparison of results gained by using the Technique for Order of Preference by Similarity to Ideal Solution (TOPSIS). The evaluated researched hypotheses and results are in the last part.

\section{Culture in the Recorded Public Sector}

The private sector should have a primary role in democratically controlled economics, but its individual failures have led to the development of the public sector, where, in the public interest, the needs of society and the population are met, usually through public goods or mixed public goods and services. Funding of public goods and services is more or less dependent on funds of public budgets. Elected representatives (public choice) decide on these public budgets, which are subject to public control and administered by public authorities.

The issue of goods was mentioned in the economics literature in [21], regarding the neoclassic theory of balance and Paret's optimum. However, the first definition of public goods is attributed to [22]. This definition was widened in the financing context by [23] and discussed by [24-29]. According to [30], market imbalance is a result of private companies failing to follow their interests and usually only trying to maximize profit for their owners, but they do not provide benefits to society as a whole.

Production and consumption of cultural goods, often ranked between mixed public goods, are in the interest of each developed state. Cultural goods are characterized by being rare and having value. These two characteristics create a base of economic value. It is difficult to set a utility value of cultural goods, because the utility value is different for each consumer. Because of this, there are extremes in the funding of relevant cultural goods. The result can be a situation where some cultural goods can be underestimated and some overrated.

\section{Evaluation of Public Goods in Culture}

It is problematic to express efficiency in public service conditions, because efficiency is not measured by profit. Since most cultural organizations primarily create no profit, the aim is to give the public services leading to user satisfaction. User satisfaction is subjective, which is why different authors have tried to find objectively measurable criteria by which the results do not necessarily have 
to be objective. One example is stating diametrically different results of different authors' evaluations of a specific area of publicly provided services.

According to [31], the social interest in the production of these goods should be viewed when evaluating public goods and services. Economists and politicians, who take care of the management of certain budgets, decide according to the interest of the population how much funding will be necessary in a given period, how the funds will be provided, and how to ensure maximal efficiency of given funds. It is stated in [32] that the expression of efficiency by public services is limited by a number of specific factors. There can be classification factors such as lack of competition, unfulfilled prices of services, lack of motivation for higher achievement, and responsibility for outputs by management, who deform and make evaluating the efficiency of public organizations more difficult $[25,33,34]$. However, economic theories offer a number of approaches to enable measuring and evaluating the efficiency of outputs and results of production processes.

Output and quality are often discussed on the market, especially by organizations working according to market principles, i.e., in the private sector. Considering that most cultural institutions operate with losses, even in developed countries (including Czech Republic), it is not possible to ensure the provision of cultural goods for profit only. This does not mean that we should not try to increase efficiency and measure the output of non-profit organizations. An organization operating according to non-profit principles is usually supported by public sources that are generally lacking. This leads not only politicians, but also professional people and non-expert public citizens, to reflect on the quantity of goods provided and their economic justification, and after some time, it leads to checking and revising services provided by public sources.

Applying efficiency management principles to public expenditure is, at the micro level, solved not only by scientists, but by organizations themselves, e.g., via benchmarking. This matter is solved at the conceptual level of economic theory, value for money (VFM), as stated in [35-38]. Public pressure forces cultural organizations, supported by public sources, to watch and improve their services and increase output to compete with other organizations on the market (but not on the profit principle) and to ensure their long-term existence.

Within the value for money concept, the efficiency of the organization is measured through thriftiness, efficiency, and effectiveness to achieve predetermined aims. According to [39], links among thriftiness, efficiency, and effectiveness suggest that the organization has to solve all three parameters when measuring output. Applying these " $3 \mathrm{E}$ " principles can lead to dramatic changes in the management of established public organizations. According to [40], the basis of VFM for these organizations should be to use public sources as best as possible to achieve the intended aims, whereas the organization should be responsible for thrifty, effective, and efficient management. In practice, it does not have to be achieving the lowest price, but should be an optimal combination of outlay and gained quality of provided cultural (public) good.

Recently, evaluating cultural organizations is very popular, as evidenced by many professional theses and publications in the arts and evaluations of economic operations. It was mentioned in [41,42], focusing on strategies for classical music, museums, or theatres for their visitors. In [14], the authors looked at strategies for long-term client sustainability of museums, theatres, and libraries, and stated that the activity of cultural institutions is not only to sustain culture, but also overlaps with social, economic, and environmental levels.

\section{Theatrical Creation in the Czech Republic and Its Funding}

There is no strict definition for the concept of theatre. There are many interpretations in the specialised literature. Theatre is most often described as an art form centring around different kinds of art (recitation, singing, music, and others). Theatrical plays approximate man in society and working society with man since ancient times. As commented in [43], it has never happened that an era was without plays, and on top of that, synthetic plays, as theatre is. In [31], the authors state that theatre has transferred meaning and can be understood as a place of wonder, creating fictions, and showing them 
as reality. Theatre is explained in [44] as a manmade art activity operated by certain institutions. If the theatre is understood as a social institution, it can be defined as an organization creating conditions for the theatrical process, and within this process there is the theatre's activity.

In several developmental stages of human history (including in the Czech Republic), theatre reflected political and social situations, and was an effective tool to influence social reality. Theatres in the Czech Republic changed after the end of the totalitarian regime in the 1990s, and according to [45], were no longer a primary tool for politicians to influence social perception. One thing is certain: The theatre had, has, and will have an irreplaceable role in people's education, their cultural self-determination, and realization of reality, in the context of wishes, imagination, and dreams, that can be an escape from everyday worries and responsibilities.

In terms of legal status, according to [46], cultural organizations in the Czech Republic are often established as state-funded organizations, and their income self-sufficiency depends on the kind of services they provide. Among cultural organizations, libraries are the least self-sufficient $(8.31 \%)$, then museums $(16.48 \%)$ and theatres $(27.21 \%)$. It is clear from these data that cultural organizations in the Czech Republic significantly depend on founders' contributions (municipalities, regions, or states).

Recent theatrical creations break records [47], not only in numbers of performances, but in numbers of places where performances occur, connected to number of scenes and reported number of theatre visitors. This is one of the reasons for the chosen technical and efficiency indices for evaluation of theatres. Other indices evaluated are connected with the financial side and the economic operation of theatres. Theatre management is responsible for these indices, as well as technical and technical-efficiency indices. Theatrical management is, according to [48], a summary of approaches, knowledge, personal opinions, and processes used by managers for successful functioning. Functions such as planning, organizing, controlling human resources, leading and checking activities in the theatre are focused on achieving outlined goals and fulfil the mission. Funding of theatres can be understood as ensuring service (total cost) by gained funds. If the management ensures sufficient funds, it can subsequently fulfil the outlined aims. If a theatre has enough funds, it also has the possibility to improve the services it provides.

Management of professional theatres in the current Czech Republic is a longer time put into envious worthy situation. On the one hand, there is an effort to operate theatres professionally, usually according to long-term declared art plans, and on the other hand, it is necessary to scrape by on a budget. The financial resources necessary to operate most theatres come from the public or different government levels (state, region, municipality), and they reflect the willingness of theatre founders to keep and fund cultural offerings for the population. These are sorted as mixed public goods because they have mostly public funding. The amount of funds for the operation of theatres in the Czech Republic depends on:

- The economic situation of the founder and the political will to fund certain kinds of cultural goods.

- The ability of management to gain financial resources from their own creations, that is, independently selecting the theatre repertoire and applying a pricing policy (income from entrance fees).

- The amount of financial resources gained by selling and operating other activities (e.g., refreshments), leasing unused rooms (e.g., halls, temporary accommodations).

- Possible gain by long-term work with other businesses or donors or art patrons (fundraising, crowdfunding).

Current funding of theatres in the Czech Republic is not based on any specific legal act. According to [49], in 1997, a model was prepared that defined multi-source funding as well as transparency and introduced professional and public decisions about state subsidies for theatres; nevertheless, a legal act determining a relationship between the state and theatres has never been accepted. According to [50], the theatre should be taken as a public service that should be obligatory financially supported by the state, but the state cannot exert direct influence on theatre management and distribution of financial resources. 
According to valid cultural policy (Ministry of Culture of the Czech Republic), there is consensus on the need to ensure financial independence of theatres through a diverse scale of financial resources. In terms of public resources provided from the state budget of the Czech Republic Ministry of Culture, criteria for funding theatres are updated every year. These criteria are published in advance, and it is up to theatre management to request funds through non-entitlement subsidies. However, it is necessary to mention that in order to meet the criteria, the amount of subsidy provided by the Ministry of Culture (state budget) is only a percentage of the total cost of theatre operation. It is often different for subsidies from budgets of founders, municipalities, or regions. The conditions for providing subsidies are different for theatres founded by territorial self-government. Except for the capital, Prague, and statutory city Brno, there is usually only one theatre in most municipalities, or a few theatres (Ostrava, City of Pilsen), and they are essentially different from each other in their produced art style (theatre genre).

\section{Materials and Methods}

The aim of this research is to conduct a complex evaluation of theatres in the Czech Republic in terms of their economic efficiency using a comprehensive multi-criteria evaluation showing the real state of evaluated subjects, and, by using the procedures and methods below, to answer the following research questions:

RQ1: Is it possible to evaluate theatres of the Czech Republic using multi-criteria analysis?

RQ2: Does the choice of method for setting the importance of indicators have a significant effect on the evaluation of efficiency of theatre management in the Czech Republic?

The basic assumption of the first research question (RQ1) is necessary to determine the heterogeneous composition of evaluated indicators. Regarding theatre as a public subject whose primary aim is not to gain profit or maximize market value, how much is necessary to cover not only financial indicators, but indicators showing technical efficiency (ability to ensure public goods) in the evaluation? The second research question (RQ2) focuses on interpreting the results of the multi-criteria evaluation in terms of the importance of individual indicators that enter into the evaluation process. They can be set by using different approaches described in a separate section. The research hypotheses for both research questions were set as follows:

RH1: We suppose that all observed indicators are significant in the multi-criteria evaluation of theatres, i.e., their weight is not zero.

RH2: We suppose that there is a statistically significant difference in weights assigned by the chosen methods in setting their importance.

If $\mathrm{RH} 2$ is confirmed, it will be possible to define the third hypothesis; its base assumption is heterogeneity of the importance of indicators using different evaluation methods.

RH3: We suppose that there is a statistically significant difference in the results of multi-criteria evaluation obtained based on the methods used.

In order to achieve this aim and answer the research questions, we used TOPSIS, which is often used with other methods to set the importance of indicators. Within the submitted research, 3 objective methods were used to set the importance of indicators that were applied for the evaluation of 11 indicators. We pay attention to their characteristics in the next part, where 26 theatres, representing a basic set from the Czech Republic, are evaluated using data of the last available year, 2015.

Common characteristics of the compared theatres (Table 1) are the existence of a professional ensemble, membership in the Association of Czech Professional Theatres, and operation by public self-government. The founder of each of the evaluated theatres is a municipality, self-government region, or Ministry of Culture of the Czech Republic. 
Table 1. Basic set of evaluated subjects (theatres).

\begin{tabular}{cccc}
\hline & Theatre & & Theatre \\
\hline T1 & CED Brno & T14 & Naivní divadlo Liberec \\
T2 & Divadlo ALFA Plzeň & T15 & Národní divadlo Brno \\
T3 & Divadlo F. X. Šaldy v Liberci & T16 & Národní divadlo moravskoslezské Ostrava \\
T4 & Divadlo J. K. Tyla Plzeň & T17 & Národní divadlo Praha \\
T5 & Divadlo Na zábradlí Praha & T18 & Slezské divadlo Opava \\
T6 & Divadlo Př́bram (Antonína Dvoř́ka) & T19 & Slovácké divadlo Uherské Hradiště \\
T7 & Horácké divadlo Jihlava & T20 & Těšínské divadlo Český Těšín \\
T8 & Jihočeské divadlo České Budějovice & T21 & Východočeské divadlo Pardubice \\
T9 & Loutkové divadlo Radost Brno & T22 & Západočeské divadlo Cheb \\
T10 & Městská divadla pražská & T23 & Dejvické divadlo \\
T11 & Městské divadlo Brno & T24 & Divadlo Drak Hradec Králové \\
T12 & Městské divadlo Zlín & T25 & Klicperovo divadlo Hradec Králové \\
T13 & Moravské divadlo Olomouc & T26 & Severočeské divadlo opery a baletu \\
\hline
\end{tabular}

The results were evaluated using a mathematical statistical method, and all calculations and analysis were conducted in MS Excel, Statistica 13.4, and Statgraphics XVIII.

\subsection{Structure of Evaluated Indicators}

First, we worked with a large number of indicators that can be considered for a multi-criteria evaluation of a basic set of 26 theatres in the Czech Republic. We approached the selection because of duplicate informative value, and the result was a set of 11 indicators. Their structure is shown in Table 2.

Table 2. Final set of evaluated indicators.

\begin{tabular}{lccc}
\hline & Indicator & Character & Group \\
\hline IT1 & Number of seats & MAX & \\
IT2 & Number of scenes (stages) & MAX & Technical \\
IT3 & Number of shows & MAX & indicators \\
IT4 & Number of premiers & MAX & \\
IT5 & Number of viewers (in thousands) & MAX & \\
IF1 & Total revenue (in mil. EUR) & MAX & \\
IF2 & Total costs (in mil. EUR) & MAX & Financial \\
IF3 & Own revenues (in mil. EUR) & MIN & indicators \\
IF4 & All subsidies (in mil. EUR) & MIN & \\
IF5 & Labour costs (in mil. EUR) & MIN & \\
IF6 & Energy consumption of main activity (in mil. EUR) & & \\
\hline
\end{tabular}

Since, as mentioned, a theatre under public administration does not aim to gain income or maximize its market value, we divided the observed indicators into two groups: Those showing technical performance and those showing financial performance.

Despite the above, we believe that subjects of public administration must keep specific rules of financial discipline. They reflect a legal regulation of public finance management that must be economical, efficient and effective. That is why we included their own income or personal expenses in the set of observed indicators. On the other side, theatre provides a public good that can be measured technically. It is necessary to account for the quality of provided goods as well conduct a complex evaluation, e.g., number of seats or number of performances.

Indicators showing technical performance, characterizing professional theatre activity, were drawn from the annual reports of individual theatres. Chosen indicators showing financial performance were converted from Czech crowns into euros, at the rate of the European Central Bank, because of the location of the Czech Republic, which should serve readers for better comparison and interpretation.

We consider that, based on this composition of indicators, it is possible to comprehensively evaluate the efficiency of theatres using multi-criteria analysis and, based on the obtained results, 
recommend concrete measures. Within the chosen multi-criteria decision making (MCDM) method, determining the importance of individual indicators is the focus of the next part.

\subsection{TOPSIS from the View of Indicator Importance}

TOPSIS is an MCDM method with high utilization rate by solving decision making problems of different characteristics. In [51], it was classified as the second most used, and alternatives include analytical hierarchy process (AHP), analytic network process (ANP), preference ranking organization method for enrichment evaluation (ROMETHEE), and elimination and choice expressing the reality (ELECTRE); [52] deals with their frequency of use.

The results can be described simply as values calculated based on the shortest distance to a positive ideal solution (i.e., variants that can be real but fictitious as well) and the longest distance to a negative ideal solution. This method is dealt with more deeply in [53,54], and setting the importance of indicators is the third step of the calculation, as follows [55]:

$$
v_{i j}=w_{i j} * r_{i j}
$$

where $v_{i j}$ is the weighted normalized value of indicator $j$ and variant $i$; $w_{i j}$ is the weight of the criteria; and $r_{i j}$ is the normalized value of indicator $j$ and variant $i$.

From the above, the direct influence of total results of TOPSIS by weight is clear, i.e., the importance of individual indicators. There are more approaches to determining them; [56] divides these approaches into four basic groups: Subjective, professional, objective, and integrated (a combination of previous approaches).

The first group, created by subjective methods, reflects the personality and individuality of decision makers who, according to their own opinions (mostly professional), set the importance of individual indicators. Expert evaluation, i.e., evaluation of a group composed of larger or smaller numbers of professionals in a given sphere, creates the second group of methods (e.g., Fuller method, Fuller triangle). The third group, created by objective methods, assigns the weights of individual indicators based on a predetermined mathematical model, unique for every method, without any influence by decision makers on the results (weight is given by the characteristics of the data). Decision makers influence the results only by choosing the method. We chose three methods for evaluating the basic set of 26 theatres in the Czech Republic: Coefficient of variance (CV), standard deviation (SD), and mean weight (MW).

The selection of methods was preceded by a review of the professional literature and the results of other research in this field. The use of coefficient of variation is different in academia, starting by moment characteristics $[57,58]$ or control CV charts [59-61]. Its practical use was part of the research of $[62,63]$. The SD method allocates weights based on the variability of individual indicators, i.e., the relative moment characteristics, which is also often used in academia [64-67]. An indicator with the highest rate of absolute variability is evaluated as the most important, and its application is offered by the research of [68]. The MW method is the simplest in its process when the weight of all indicators is equal [69].

Based on the conclusion of the theoretical part, where we state the homogeneity of funding across all theatres in the Czech Republic, these three methods were selected because of their different approaches to evaluating the importance of indicators.

The intention of this selection is to show the possibility of comprehensively evaluating the basic set (RQ1) and significant differences determined by this selection in setting the importance of indicators (RQ2), as mentioned in [70].

\section{Comprehensive Evaluation of Theatre Performance in the Czech Republic}

In the context of above information, the analysis was divided into four smaller parts. They led to recommendations and suggestions for practice discussed in the conclusion. In the first part (Section 5.1), 
we focus on determining the importance of evaluated indicators using the three methods: CV, SD, and MW. The basic set of 26 theatres in the Czech Republic was separately evaluated by combinations of methods in the three next parts: CV-TOPSIS (Section 5.2), SD-TOPSIS (Section 5.3), and MW-TOPSIS (Section 5.4). In the last part (Section 5.5), the obtained results are statistically verified using wide array of mathematical statistical methods, including Kendall rank coefficient, Kolmogorov-Smirnov test $(\mathrm{K}-\mathrm{S})$, Kruskal-Wallis test (Q), Levene test (LE), and sign test (U).

\subsection{Evaluation of Indicator Importance}

The basic step to directly determine the result of multi-criteria evaluation (TOPSIS or other MCDM method) is to determine the importance of indicators importance input into the calculation. There are other approaches, but for the purposes of this paper, three objective methods were used: CV, SD, and MW, with following results.

We can see significant differences among the methods in the results of evaluating indicator importance (Figure 1). CV assigned the biggest importance mainly to financial indicators; they were evaluated as more important than technical indicators. Using this method, a theatre's own income was evaluated as the most important indicator (IF3), followed by total income (IF1) and total costs (IF2). SD shows a different view of indicator structure, with technical indicators such as number of seats (IT1), number of performances (IT3), and number of spectators (IT5) having the highest weights. Logically, according to the calculation by MW, all indicators are equal.

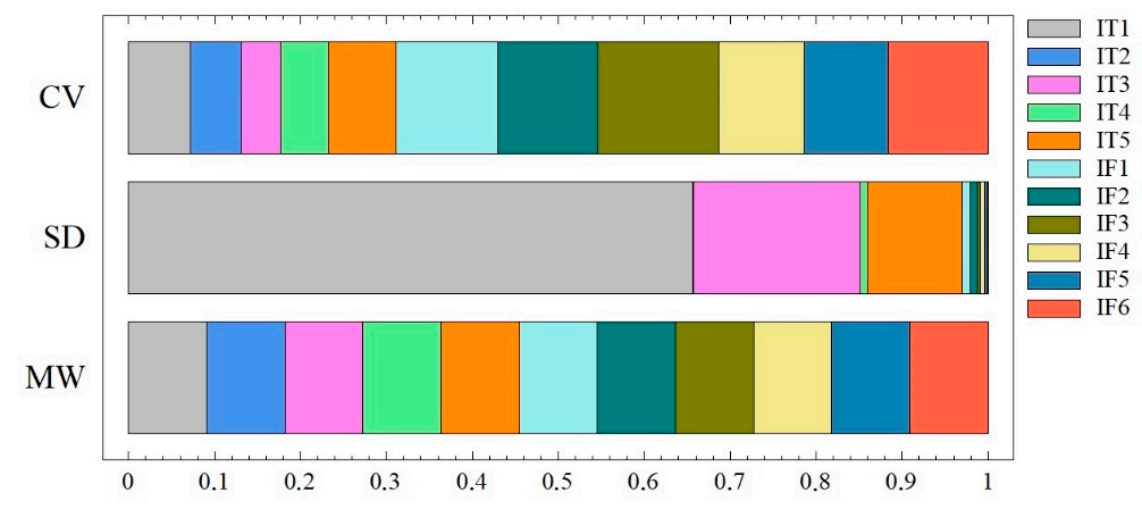

Figure 1. Importance of indicators using coefficient of variance (CV), standard deviation (SD), and mean weight (MW) methods.

These differences appeared in total stress on observed fields, i.e., in the technical and financial evaluation of theatres (see Figure 2). CV places more emphasis on financial aspects, but SD shows these aspects as secondary. The group of financial indicators has a major influence on the results in this case. Considering MW, importance is given by the quality of indicators in the individual field, so it is not possible to state a preference for one or another field.

From the view of total structure, we note significant differences between weights assigned by the SD method and couple of CV and MW methods $\left(\mathrm{K}-\mathrm{S}_{\mathrm{CV} / \mathrm{SD}}=1.705 ; p<0.01 ; \mathrm{K}-\mathrm{S}_{\mathrm{CV} / \mathrm{MW}}=1.279\right.$; $\left.p=0.076 ; \mathrm{K}-\mathrm{S}_{\mathrm{SD} / \mathrm{MW}}=1.705 ; p<0.01\right)$. Since the weight of indicators is assigned according to individual methods (see Figure 3), we confirm RH1, i.e., all observed indicators are significant in the multi-criteria evaluation of theatres. We also identified a statistically significant difference in weights assigned by the chosen methods in determining their importance, confirming RH2. 


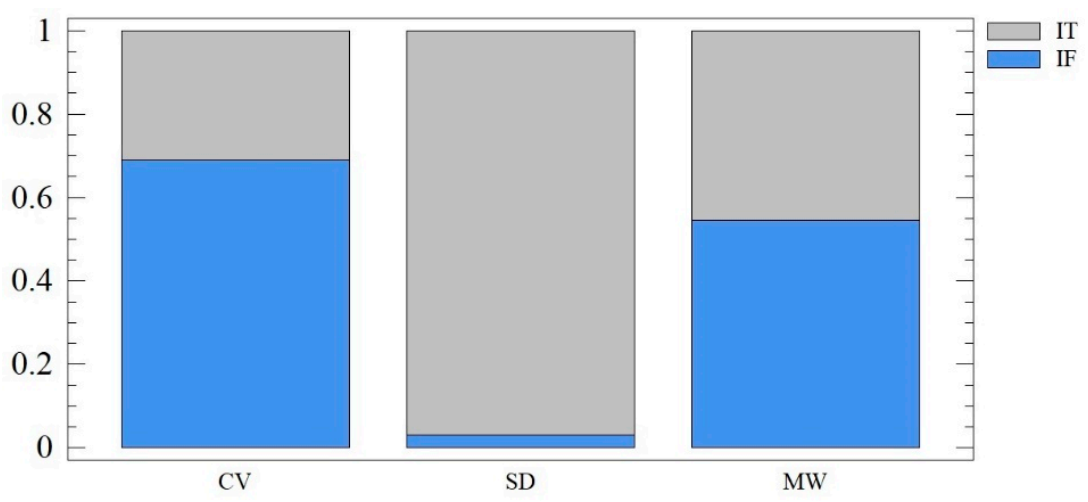

Figure 2. Importance of financial and technical indicators using CV, SD, and MW.

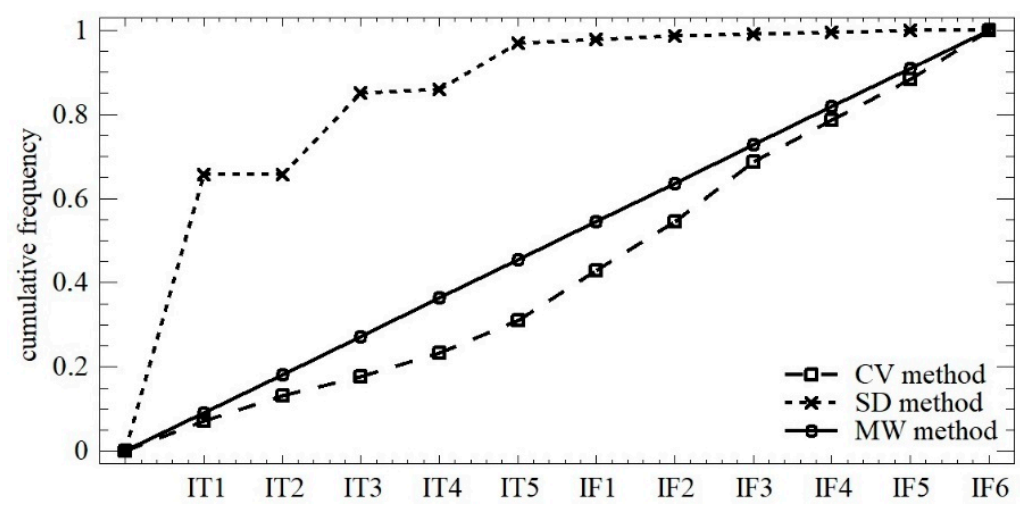

Figure 3. Cumulative frequency of individual indicator weights using CV, SD, and MW.

\subsection{Evaluation of Performance Using CV-TOPSIS}

The results of the first combination, TOPSIS and CV, for determining indicator importance show a high rate of balance, proving their minimal variation margin $(R=0.065)$. The low rate of variability is also confirmed at the level of absolute $\left(\mathrm{s}_{\mathrm{X}}=0.146\right)$ and relative $\left(\mathrm{v}_{\mathrm{X}}=2.922 \%\right)$ torque characteristics, reflected in the high rate of concentration of results about the mean $(\beta=3.598)$. Figure 4 shows the total structure of these results.

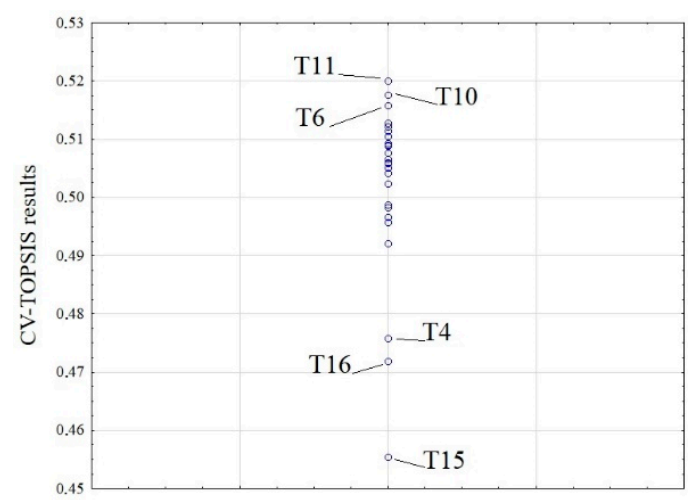

Figure 4. Results of evaluation of theatres using CV-TOPSIS (Coefficient of Variance-Technique for Order of Preference by Similarity to Ideal Solution).

Městské divadlo Brno (T11) is found to be the best evaluated theatre in the context of 11 observed indicators, followed by Městská divadla pražská (T10) and Divadlo Přbram (T6). Among the other theatre results, their positions can be attributed to one or a small number of indicators shifting them to the top. This underlines the necessity to deal with more aspects of the economy, and it must be seen 
more comprehensively. National Theatre Brno (T15), National Moravian-Silesian Theatre Ostrava (T16), and J.K. Tyl Theatre Pilsen (T4) were placed on the other side of the ranking. Bad values of financial indicators (IF4, IF5, and IF6) primarily caused the low ranking of these theatres. These differences are caused by the multi-genre focus of the theatres. More buildings and scenes to manage and more employees connecting with the multi-genre focus of the theatres influence the costs connected with labour and for operating main activities of the institution. These theatres would not be able to ensure their operation when providing cultural services for the population with the same quality (multi-genre performance) without high subsidies from their founders (municipalities).

In the context of the results of individual indicators, we can see better financial indicators (IF4, IF5, IF6) for better evaluated theatres (Table 3). The paradox is these theatres have smaller total income (IF1) and fewer premieres (IT4). It is necessary to perceive this in the context of low variability of total results, whereas all identified linear connections can be marked as small or medium.

Table 3. Five best and worst evaluated theatres using CV-TOPSIS.

\begin{tabular}{cccccc}
\hline \multicolumn{3}{c}{ Five Best Theatres } & \multicolumn{3}{c}{ Five Worst Theatres } \\
\hline 1. & T11 & 0.5201 & 22. & T13 & 0.4957 \\
\hline 2. & T10 & 0.5177 & 23. & T17 & 0.4921 \\
3. & T6 & 0.5158 & 24. & T4 & 0.4757 \\
4. & T21 & 0.5128 & 25. & T16 & 0.4720 \\
5. & T23 & 0.5121 & 26. & T15 & 0.4555 \\
\hline
\end{tabular}

\subsection{Evaluation of Performance Using SD-TOPSIS}

The second combination, TOPSIS and SD, for determining indicator importance, shows significantly different characteristics compared to the first combination. It is possible to see a high rate of heterogeneity by evaluating the variation margin $(R=0.728)$, caused by the dominance of one evaluated subject (see Figure 5). This dominance also resulted in a difference of the mean $(\bar{x}=0.201$; $\tilde{x}=0.124)$. In this context, we can say that the results are positively skewed with a major occurrence of below average theatres.

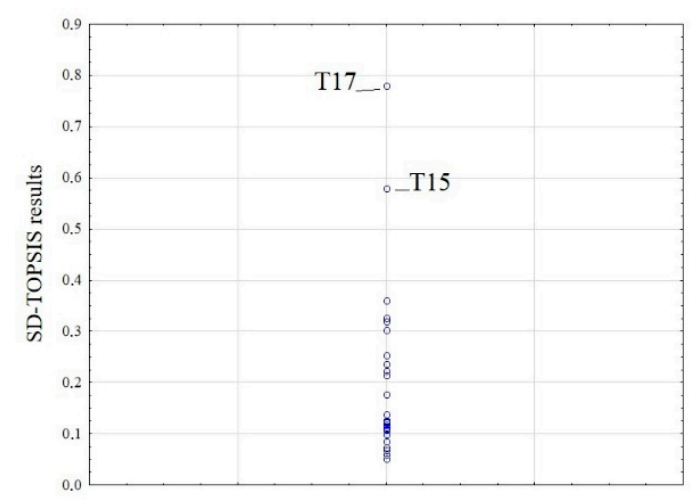

Figure 5. Results of evaluating theatres using SD-TOPSIS.

The National Theatre in Prague (T17) is significantly dominant when using SD for determining indicator importance, mainly because of technical indicators and incomes, both total and own income (IF1, IF3). The National Theatre in Brno (T15) ranked second, and its evaluation can be considered dominant compared to others. Dejvické Divadlo (T23) and Divadlo Na Zabrdli (T5) are considered as the worst theatres. Their deficiencies can be primarily seen in terms of technical indicators, partially compensated by better finance indicators, but it is not sufficient (see Table 4). 
Table 4. Five best and worst evaluated theatres using SD-TOPSIS.

\begin{tabular}{cccccc}
\hline \multicolumn{2}{c}{ Five Best Theatres } & \multicolumn{3}{c}{ Five Worst Theatres } \\
\hline 1. & T17 & 0.7791 & 22. & T22 & 0.0739 \\
2. & T15 & 0.5791 & 23. & T24 & 0.0734 \\
3. & T16 & 0.3604 & 24. & T2 & 0.0681 \\
4. & T4 & 0.3270 & 25. & T5 & 0.0589 \\
5. & T11 & 0.3198 & 26. & T23 & 0.0514 \\
\hline
\end{tabular}

Better evaluated theatres using this method show significantly better IT1 values. This is only a reflection of the importance given to this indicator. This compensates for the better ranking of theatres with a larger volume of subsidies (IF4), personal expenditures (IF5), and power consumption (IF6), i.e., indicators with minimalistic character.

\subsection{Evaluation of Performance Using MW-TOPSIS}

The last method is the combination of TOPSIS and MW for determining indicator importance, and its variability is low, as with CV-TOPSIS (see Section 4.2) with minimal variation margin, at the level of 0.071 relative distance to PIS alternative (see Figure 6). This significant homogeneity is supported by the chosen moment characteristics $\left(\mathrm{s}_{\mathrm{X}}=0.017 ; \mathrm{v}_{\mathrm{X}}=3.278 \%\right)$ and high rate of concentration of results about the mean $(\beta=3.080)$.

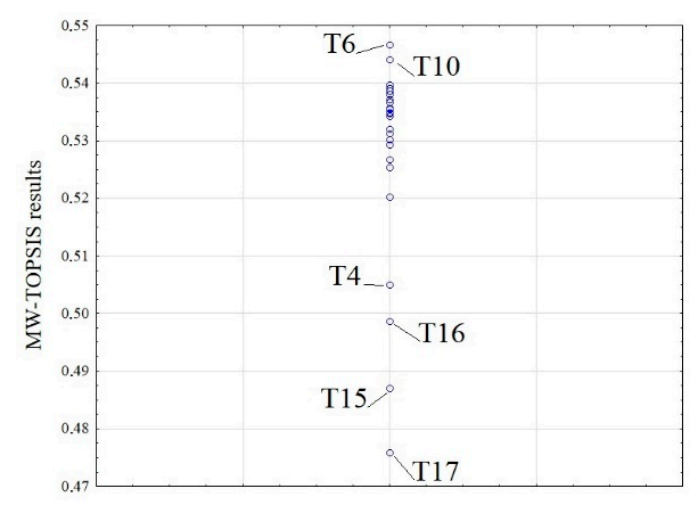

Figure 6. Results of evaluation of theatres using MW-TOPSIS.

We see stronger differences in individual theatres with the evaluation by this combination of methods, especially at the end of the ranking. The difference between the two best evaluated theatres, Divadlo Pribram (T6) and Mestske divadlo Prazske (T10), is more than 10 times smaller than the difference between the four worst evaluated theatres, National Prague Theatre (T17), National theatre Brno (T15), National Moravian-Silesian Museum Ostrava (T16), and J.K. Tyl Theatre Pilsen (T4). The financial indicators (IF4-IF6) have a major impact on this evaluation; within these indicators, the four theatres mentioned above ranked the lowest in every evaluation (in different orders).

This trend was proved in the total evaluation of results: Better total results are associated with lower total costs (IF2), subsidies (IF4), personal expenditures (IF5), and power consumption (IF6). While we can note that theatres with fewer premieres (IT4) were evaluated better, this was proved with the CV-TOPSIS combination (Table 5). 
Table 5. Five best and worst evaluated theatres using MW-TOPSIS.

\begin{tabular}{cccccc}
\hline \multicolumn{2}{c}{ Five Best Theatres } & \multicolumn{3}{c}{ Five Worst Theatres } \\
\hline 1. & $\mathrm{T} 6$ & 0.5468 & 22. & $\mathrm{~T} 13$ & 0.5203 \\
2. & $\mathrm{~T} 10$ & 0.5441 & 23. & $\mathrm{~T} 4$ & 0.5050 \\
3. & $\mathrm{~T} 25$ & 0.5397 & 24. & $\mathrm{~T} 16$ & 0.4987 \\
4. & $\mathrm{~T} 11$ & 0.5392 & 25. & $\mathrm{~T} 15$ & 0.4871 \\
5. & $\mathrm{~T} 21$ & 0.5387 & 26. & $\mathrm{~T} 17$ & 0.4758 \\
\hline
\end{tabular}

\subsection{Comparison of Results Gained Individual Methods}

We stressed the importance of individual indicators, and in previous sections they were proven to be significantly different using three methods (CV, SD, MW), leading to confirmation of RH1 and RH2. Then we rewrote the results using descriptive statistics, and we compare them here.

From the view of total structure and variability of results, we note significant differences between the results of SD-TOPSIS and CV and MW for setting indicator importance $(\mathrm{LE}=23.251 ; p<0.01)$. The results were reflected in significantly different medians, and this is attributed to high variability and positive skew of SD-TOPSIS combination results $(\mathrm{Q}=46.694 ; p<0.01)$.

A statistically significant difference of distribution function $\left(\mathrm{K}-\mathrm{S}_{\mathrm{CV} / \mathrm{SD}}=0.923 ; p<0.01\right.$; $\left.\mathrm{K}_{-\mathrm{S} / \mathrm{MW}}=0.846 ; p<0.01 ; \mathrm{K}-\mathrm{S}_{\mathrm{SD} / \mathrm{MW}}=0.923 ; p<0.01\right)$ is proven in paired comparisons of individual results. The difference is proven using the auxiliary sign test $\left(\mathrm{U}_{\mathrm{CV} / \mathrm{SD}}=4.118 ; p<0.01 ; \mathrm{U}_{\mathrm{CV} / \mathrm{MW}}=4.451 ; p\right.$ $<0.01 ; \mathrm{U}_{\mathrm{SD} / \mathrm{MW}}=4.118 ; p<0.01$ ). Based on the above (Figures 7 and 8 ), we note that there is a statistically significant difference between the total results of the multi-criteria evaluation based on the combination of methods used, confirming RH3.

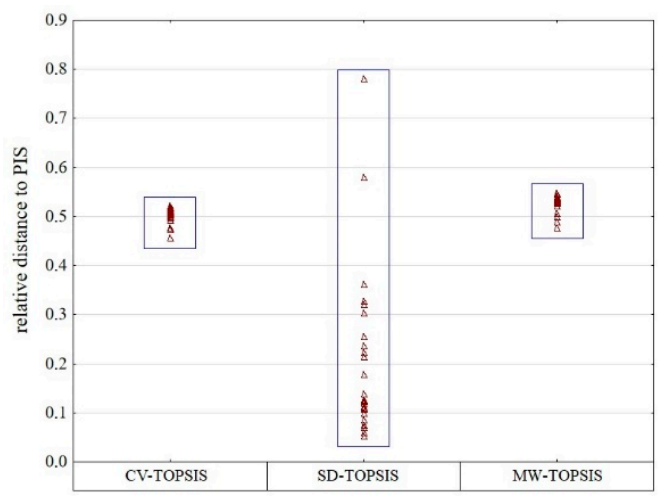

Figure 7. Comparison of result structure of theatre evaluation using individual methods.

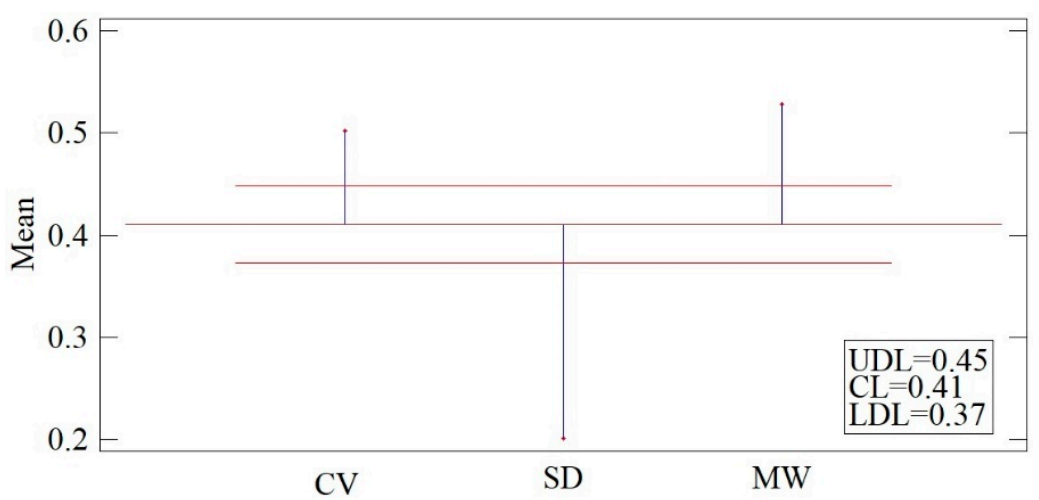

Figure 8. ANOM analysis of results of theatre evaluation using individual methods. 


\section{Discussion}

A valid cultural policy is a binding document in the cultural area in many developed countries, defining methods, processes, tools, and measures that should lead to achieving goals, which are constantly developing for a free, diverse cultural life of the population and contribute to the treasury of humanity. Cultural activities most often focus on developing and retaining cultural heritage, increasing efficiency in the cultural area, and increasing citizens' awareness. The result is that citizens feel a sense of belonging to the nation, region, city, or town, and mutual self-identification with the community of people in the territory. In this regard, culture can positively influence the perception of individuals and be a motivational tool for young people to stay in their native region and contribute to its developing stability.

Theatrical creations are developed in the Czech Republic, as demonstrated by a large number of operated scenes (for its spatial distribution see Figure 9). With regard to the number of inhabitants, the total number of theatres is rather above standard in comparison to other European countries. According to [46], theatre subjects are distributed quite evenly in a territory, however, the genre offerings of theatres are rather uneven in a territory. A specific feature of the Czech theatre infrastructure is the so-called metropolitan characteristic of theatres. There is a high concentration of different kinds of theatres in metropolises. Within the Czech Republic and theatrical creations may be recorded some exclusive status of the capital, Prague, and other large cities (Brno, Ostrava, Pilsen). There are large multi-genre theatres in these cities, and more theatre subjects that differ by diverse offerings of theatrical creations. A specific ranking of multi-genre theatres was confirmed in this paper, dependent on the chosen method of evaluation, and it is evident at first sight from the results of all variants used. In different research, there may be found supporters of both subjective [52] and objective methods [63,69], whereas [70] offers a comparison of five of them. From the results shown in the previous sections, we show a significant influence of the method selection for determining indicator importance in the total results of TOPSIS, i.e., individual research questions RH1, RH2, and RH3 were confirmed. Every method has its specifics, reflected in the result structure, or if it focuses on indicators or skew or concentration of the mean.

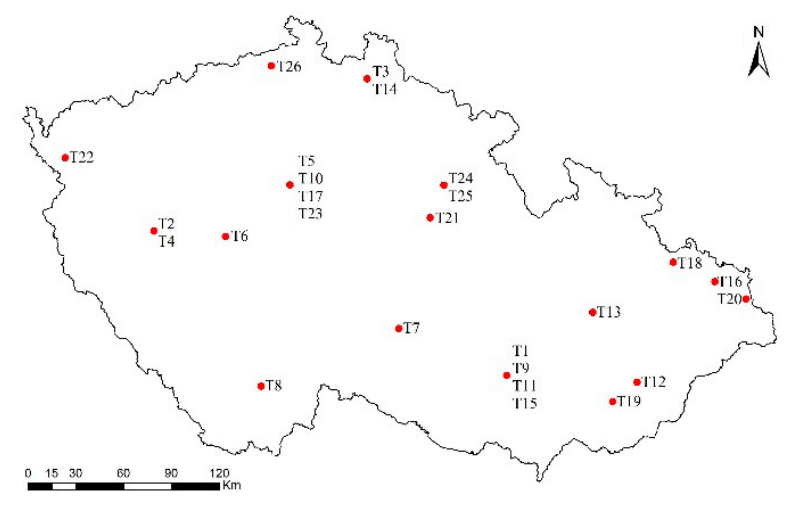

Figure 9. Spatial distribution of evaluated theatres in the Czech Republic.

The amount of funds founders have at their disposal is a problem in financing theatre activities. Funding of theatres (especially multi-ensemble) is very difficult when there is high entitlement to the subsidy of cost for their premiere. Theatres must get more involved in subsidy schemes. Funds from subsidy schemes are determined, in particular, for theatres' own creations to compete in the theatre scene. Theatre management should constantly strive for a variety of performances and thus attract more visitors and grow attendance. These factors influence the amount of subsidies from state budgets in the Czech Republic and from the Ministry of Culture.

The following arguments should contribute to the funding of cultural goods from public resources in developed economies: 
- The production, valuation, and distribution of cultural goods cannot be only for competition in the market, because the market does not respect the inner value cultural goods provides to consumers, but is focused mainly on production of maximum profit.

- The market is not able to ensure non-profit production of goods every time, in every place, and in sufficient quantity and quality.

- It is in the interest of society to support production and consumption of cultural goods because consumption leads to formation of positive externalities.

The above information is necessary to perceive in the context of the limitations of the given methodology and evaluated period. It is not possible to exactly set the best method for determining indicator importance for use in the public sector and in culture. However, every combination given above has the potential to be used as a tool for complex comparison within homogeneous groups of subjects (here, theatres in the Czech Republic) depending on user preference.

Author Contributions: Conceptualization, R.V. and J.B.; methodology, R.V.; software, R.V.; validation, R.V.; formal analysis, R.V.; investigation, R.V. and J.B.; resources, J.B.; data curation, J.B.; writing-original draft preparation, R.V. and J.B.; writing-review and editing, R.V.; visualization, R.V.; supervision, R.V; project administration, J.B.; funding acquisition, J.B. All authors have read and agreed to the published version of the manuscript.

Funding: This research was funded by the STUDENT GRANT COMPETITION IN VŠB - TECHNICAL UNIVERSITY OF OSTRAVA, grant number SP2020/32; TECHNOLOGICAL AGENCY OF THE CZECH REPUBLIC, grant number TL01000145.

Conflicts of Interest: The authors declare no conflict of interest.

\section{References}

1. Borg, J.; Russo, A.P. The Impacts of Culture on the Economic Development of Cities; European Institute for Comparative Urban Research, Erasmus University: Rotterdam, The Netherlands, 2005; pp. 1-395.

2. Throsby, D. Assessing the impacts of a cultural industry. J. Arts Manag. Law Soc. 2004, 34, 188-204. [CrossRef]

3. Throsby, D. The Economics of Cultural Policy; Cambridge University Press: Cambridge, UK, 2010; pp. 1-280.

4. UNESCO. Measuring the Economic Contribution of Cultural Industries; A review and Assessment of Current Methodological Approaches; UNESCO Institute for Statistics: Montreal, CA, USA, 2009; Available online: http:/uis.unesco.org/sites/default/files/documents/measuring-the-economic-contribution-of-cult ural-industries-a-review-and-assessment-of-current-methodological-approaches-en_1.pdf (accessed on 1 April 2020).

5. Chiarvalloti, F. Performance Evaluation in the Arts and Cultural Sector: A Story of Accounting at Its Margins. J. Arts Manag. Law Soc. 2014, 44, 61-89. [CrossRef]

6. Van Der Pol, H. Key Role of Cultural and Creative Industries in the Economy. In Statistics, Knowledge and Policy 2007: Measuring and Fostering the Progress of Societies; Organisation for Economic Co-operation and Development: Paris, France, 2007; Available online: https://www.oecd-ilibrary.org/docserver/9789264043244-en.pdf?expires $=1585812571 \& \mathrm{id}=\mathrm{id} \&$ accname$=$ guest\&checksum $=098625$ EF72FB7D19CAEEE882CBA279A. (accessed on 1 April 2020).

7. Mukti, K. Culture and Commerce: The Value of Entrepreneurship in Creative Industries; Stanford Business Books: Stanford, CA, USA, 2017; pp. 1-280.

8. Meineck, P. Page and stage: Theater, tradition, and culture in America. Class. World 2010, 103, 221-226. [CrossRef]

9. Julien, M. Community, viability: Theatre past and present. Can. Theatre Rev. 2017, 169, 78-83. [CrossRef]

10. Corbos, R.A.; Popescu, R.I. Study regarding Theatres' role in increasing urban competitiveness. Adm. Manag. Public 2013, 20, 78-96.

11. Ardielli, E.; Bečica, J. Multi-criteria Evaluation of the State of Professional Theatres in the Czech Republic in Terms of Mixed Public Goods Provided to the Citizens. Rev. Econ. Perspect. 2018, 18, 155-176. [CrossRef]

12. Bečica, J. Income Self-Sufficiency and Profitability of Professional Theatres in the Czech Republic. Rev. Econ. Perspect. 2018, 18, 285-299. [CrossRef] 
13. Galecka, M.; Smolny, K. Criteria for the optimal financing model of public theatres. Rev. Econ. Perspect. 2019, 19, 119-136. [CrossRef]

14. Loach, K.; Rowley, J.; Griffiths, J. Cultural sustainability as a strategy for the survival of museums and libraries. Int. J. Cult. Pol. 2017, 23, 186-198. [CrossRef]

15. Rushton, M. Cultural diversity and public funding of the arts: A view from cultural economics. J. Arts Manag. Law Soc. 2003, 33, 85-97. [CrossRef]

16. Peacock, A. The credibility of cultural economists' advice to governments. Conytib. Econ. Anal. 2004, 260, 165-178.

17. Throsby, D. Why should economists be interested in cultural policy? Econ. Rec. 2012, 88, 106-109. [CrossRef]

18. Towse, R. Advanced Introduction to Cultural Economics; Edward Elgar Publishing: Cheltenham, UK, 2014; pp. 1-160.

19. Frey, B.S. Arts E Economics: Analysis \& Cultural Policy; Springer: Berlin, Germany, 2000; pp. 1-210.

20. Volz, J. Introduction to Art Management; Bloomsbury Publishing: London, UK, 2017; pp. 1-274.

21. Pareto, V.; Schwier, A.S. Manual of Political Economy; August M. Kelley Pubs: New York, NY, USA, 1927; pp. 1-504.

22. Samuelson, P.A. The Pure Theory of Public Expenditure. Rev. Econ. Stat. 1954, 36, 387-389. [CrossRef]

23. Musgrave, R.A. The Theory of Public Finance; McGraw-Hill: New York, NY, USA, 1959; pp. 1-90.

24. Arrow, K. Social Choice and Individual Values; John Wiley \& Sons: New York, NY, USA, 1963; pp. 1-144.

25. Niskanen, W.A. Bureaucracy and Representative Government; Aldine-Atherton: Chicago, IL, USA, 1971; pp. 1-297.

26. Pollitt, C. Managerialism and the Public Services: Cult for Cultural Change in the 1990s? Blackwell: Oxford, UK, 1993; pp. 1-256.

27. Buchanan, J. Veřejné Finance v Demokratickém Systému; Computer Press: Prague, Czech Republic, 1998; pp. 1-344.

28. Samuelson, P.A.; Nordhaus, W.D. Economics; McGraw-Hill: New York, NY, USA, 2010; pp. 1-974.

29. Stiglitz, J.E. Ekonomie Veřejného Sektoru; Grada Publishing: Prague, Czech Republic, 1997; pp. 1-661.

30. Stiglitz, J.E.; Rosengard, J.K. Economics of the Public Sector; W. W. Norton Company: New York, NY, USA, 2015; pp. 1-960.

31. Bernard, J. Co je Divadlo; SPN: Prague, Czech Republic, 1983; pp. 1-20.

32. Leibenstein, H. Allocative efficiency vs "X-Efficiency". Am. Econ. Rev. 1966, 56, 392-415.

33. Lane, J.E. New Public Management; Routledge: London, UK, 2000; pp. 1-262.

34. Dooren, W.; Bouckaert, G.; Halligan, J. Performance Management in the Public Sector; Routledge: New York, NY, USA, 2010; pp. 1-13.

35. Boyne, G.A. Public and private management: What's the difference? J. Man. Stud. 2002, 39, 97-122. [CrossRef]

36. Radnor, Z.; McGuire, M. Performance management in the public sector: Fact or fiction? Int. J. Prod. Perform. Manag. 2004, 53, 45-60. [CrossRef]

37. Emery, Y.; Wyser, C.; Martin, N.; Sanchez, J. Swiss public servants' perceptions of performance in a fast-changing environment. Int. Rev. Admin. Sci. 2008, 74, 307-323. [CrossRef]

38. Antinoja, E.; Eskiocak, O.; Kjennerud, M.; Rozenkopf, I.; Schatz, F. Value for Money: Current Approaches and Evolving Debates; London, May 2011; London School of Economics and Political Science: London, UK, 2011; Available online: http://bigpushforward.net/wp-content/uploads/2011/09/vfm-current-approaches-and-evo lving-debates.pdf (accessed on 14 January 2020).

39. Curry, A. Innovation in public service management. Man. Ser. Qual.: An Int. J. 1999, 9, 180-190. [CrossRef]

40. Kaluganga, M.; Kakwezi, P. Value for money auditing and audit evidence from a procurement perspective-A conceptual paper. Int. J. Adv. Manag. Econ. 2013, 2, 115-124.

41. Frey, B.S. Arts E Economics: Analysis E Cultural Policy; University of Zurich: Zurich, Switzerland, 2003; pp. 1-246.

42. Kolb, B. Marketing for Cultural Organisations: New Strategies for Attracting Audiences to Clascical Music, Dance, Museums, Theatre and Opera; Thomson: London, UK, 2005; pp. 1-250.

43. Blahník, V.K. Smysl a Podstata Divadelního Umění; Fratišek Borový: Prague, Czech Republic, 1923; pp. 1-20. 
44. Černý, F. Metodologie Výzkumu Dějin Divadla: Skripta pro Posluchače Filozofické Fakulty Univerzity Karlovy; Charles University in Prague: Prague, Czech Republic, 1982; pp. 1-20.

45. Dvořák, J. Kreativní Management pro Divadlo, Aneb, O Divadle Jinak: Kapitoly k Tématu Realizace Divadla; Pražská Scéna: Prague, Czech Republic, 2004; pp. 15-30.

46. Vrabková, I.; Vaňková, I.; Bečica, J.; Kryšková, Š. Příspěvkové Organizace: Postavení, Úkoly a Technická Efektivnost; VŠB-TUO: Ostrava, Czech Republic, 2017; pp. 1-189.

47. NIPOS. Kultura České Republiky v Číslech: Vybrané Údaje ze Statistických Šetření; Národní Informační a Poradenské Středisko pro Kulturu: Prague, Czech Republic, 2015; pp. 1-31.

48. Krejčí, H. Základní Typy Právních Forem Profesionálních Divadel v České Republice a Jejich Vliv na Proces Řízení; Janáčkova Akademie Múzických Umění v Brně: Brno, Czech Republic, 2009; pp. 1-214.

49. Nekolný, B. Studie Současného Stavu Podpory Umění; Institut Umění: Prague, Czech Republic, 2009.

50. Šimek, Š. Financing of Czech Theatre/Financování Českého Divadla. Available online: https://www.culturen et.cz/knihovna/financing-of-czech-theatre-financovani-ceskeho-divadla (accessed on 22 January 2020).

51. Zavadskas, E.K.; Mardani, A.; Turskis, Z.; Jusoh, A.; Nor, K. Development of TOPSIS Method to Solve Complicated Decision-Making Problems: An Overview on Developments from 2000 to 2015. Int. J. Inf. Technol. Decis. Mak. 2016, 15, 1-38. [CrossRef]

52. Tramarico, C.L.; Mizuno, D.; Antonio, V.; Salomon, P.; Augusto, F.; Marins, S. Analytic Hierarchy Process and Supply Chain Management: A Bibliometric Study. Procedia Comput. Sci. 2015, 55, 441-450. [CrossRef]

53. Shih, H.S.; Shyur, H.J.; Lee, E.S. An extension of TOPSIS for group decision making. Math. Comput. Model. 2007, 45, 801-813. [CrossRef]

54. Seyedmohammadi, J.; Sarmadian, F.; Jafarzadeh, A.A.; Ghorbani, M.A.; Shahbazi, F. Application of SAW, TOPSIS and fuzzy TOPSIS models in cultivation priority planning for maize, rapeseed and soybean crops. Geoderma 2018, 310, 178-190. [CrossRef]

55. Vavrek, R.; Kotulič, R.; Adamišin, P. Evaluation of Municipalities Management with the Topsis Technique Emphasising on the Impact of Weights of Established Criteria. Lex Loc. 2015, 13, 249-264. [CrossRef]

56. Keršuliene, V.; Zavadskas, E.K.; Turskis, Z. Selection of rational dispute resolution method by applying new step-wise weight assessment ratio analysis (SWARA). J. Bus. Econ. Manag. 2010, 11, 243-258. [CrossRef]

57. Girling, A.J. Relative efficiency of unequal cluster sizes in stepped wedge and other trial designs under longitudinal or cross-sectional sampling. Stat. Med. 2018, 37, 4652-4664. [CrossRef]

58. Thangjai, W.; Niwitpong, S.A. Confidence intervals for the weighted coefficients of variation of two-parameter exponential distributions. Cog. Math. 2017, 4, 1315880. [CrossRef]

59. Tran, K.P.; Heuchenne, C.; Balakrishnan, N. On the performance of coefficient of variation charts in the presence of measurement errors. Qual. Rel. Eng. Int. 2019, 35, 329-350. [CrossRef]

60. Muhammad, A.N.B.; Yeong, W.C.; Chong, Z.L.; Lim, S.L. Monitoring the coefficient of variation using a variable sample size EWMA chart. Comput. Ind. Eng. 2018, 126, 378-398. [CrossRef]

61. Zhang, J.J.; Li, Z.H.; Wang, Z.J. Control chart for monitoring the coefficient of variation with an exponentially weighted moving average procedure. Qual. Rel. Eng. Int. 2018, 34, 188-202. [CrossRef]

62. Bhowate, A.; Aware, M.; Sharma, S. Predictive Torque Control with Online Weighting Factor Computation Technique to Improve Performance of induction Motor Drive in Low Speed Region. IEEE Access 2019, 7, 42309-42321. [CrossRef]

63. Vavrek, R.; Chovancová, J. Assessment of economic and environmental energy performance of EU countries using CV-TOPSIS technique. Ecol. Ind. 2019, 106, 105519. [CrossRef]

64. Xing, H.F.; Chen, Z.Y.; Zhang, X.X.; Yang, H.T.; Gou, M.F. Optimal Weighted Fusion Based on Recursive Least Squares for Dynamic North-Finding of MIMU on a Tilting Base. IEEE Access 2019, 7, 96215-96222. [CrossRef]

65. Feng, Z.Y.; Cao, C.X.; Liu, Y.T.; Zhou, Y.L. A Multiobjective Optimization for Train Routing at the High-Speed Railway Station Based on Tabu Search Algorithm. Math. Prob. Eng. 2018, 2018, 22. [CrossRef]

66. Zhu, Y.; Guan, Y.Q.; Xie, N.M.; Wang, N. Modified Grey Variable Weight Clustering Method Based on Standard Deviation and Its Application. J. Gr. Syst. 2018, 30, 1-13. [CrossRef]

67. Chen, C.H.; Chou, C.Y. Optimum process mean, standard deviation and specification limits settings under the Burr distribution. Eng. Comput. 2017, 34, 66-76. [CrossRef] 
68. Ouerghi, H.; Mourali, O.; Zagrouba, E. Non-subsampled shearlet transform based MRI and PET brain image fusion using simplified pulse coupled neural network and weight local features in YIQ colour space. IET Image Proc. 2018, 10, 1873-1880. [CrossRef]

69. Vavrek, R.; Adamišin, P.; Kotulič, R. Multi-Criteria Evaluation of Municipalities in Slovakia-Case Study in Selected Districts. Pol. J. Manag. Stud. 2017, 16, 290-301. [CrossRef]

70. Vavrek, R. Evaluation of the Impact of Selected Weighting Methods on the Results of the TOPSIS Technique. Int. J. Inf. Technol. Decis. Mak. 2019, 18, 1821-1843. [CrossRef]

(C) 2020 by the authors. Licensee MDPI, Basel, Switzerland. This article is an open access article distributed under the terms and conditions of the Creative Commons Attribution (CC BY) license (http://creativecommons.org/licenses/by/4.0/). 